\title{
Geochemistry evidence for depositional settings and provenance of Jurassic argillaceous rocks of Jiyuan Basin, North China
}

\author{
Yao Meng ${ }^{1}$, Deshun Zheng ${ }^{1, *}$ and Minglong LI $^{2}$ \\ ${ }^{1}$ School of Resources and Environment, Henan Polytechnic University, Jiaozuo, Henan 454000, China. \\ ${ }^{2}$ Second Geological Bridge of Hubei Geological Bureau, Enshi, Hubei 445000, China. \\ *Corresponding author. e-mail: zhengdeshun@hpu.edu.cn
}

This paper aims to discuss the depositional settings and provenances for the Jurassic in Jiyuan basin, North China, based on the rare earth element (REE) and trace element features of 16 Jurassic argillaceous rock samples from the Anyao, Yangshuzhuang and Ma'ao Formations, respectively. Generally, geochemical analysis results show that chondrite-normalised REE distribution patterns of all the three formations are characterised by light-REE (LREE) enrichment, moderately negative Eu anomalies, slightly negative Ce anomalies, and strong fractionation between LREE and heavy-REE (HREE). Trace element proxies $\mathrm{V} /(\mathrm{V}+\mathrm{Ni}), \mathrm{Ce}_{\text {anom }}$ index, $\mathrm{Ce} / \mathrm{La}, \mathrm{Sr} / \mathrm{Ba}$, and $\mathrm{Sr} / \mathrm{Cu}$ indicate a weak oxidation-reduction environment, progressively decreasing reducibility and water depth from the bottom up during Jurassic in Jiyuan basin. Palaeoclimate varied from humid in the Early Jurassic to arid in the Middle Jurassic, corresponding with the variations of palaeoredox and palaeosalinity. The provenances of Jurassic rocks in Jiyuan basin are mainly from felsic sources related to active continental margin and continental island arc. The Early-Middle Jurassic (Anyao and Yangshuzhuang Formations) provenances are mainly derived from North Qinling and partially from the eroded recycled felsic sedimentary covers of Taihang Mountain. In the late stage of Middle Jurassic (Ma'ao Formation), Taihang Mountain has been the primary source to Jiyuan basin. We conclude that the Jurassic rocks of Jiyuan basin reveal the progressive uplift and denudation processes of the Taihang Mountain.

\section{Introduction}

The North China Craton (NCC) is bound by the Qinling-Dabie orogen to the south, the Yinshan orogen to the north, the Longshoushan belt to the west and the Sulu HP-UHP metamorphic belt to the east (Zhang 1997, 2002, 2004; Zhao et al. 2005; Zhang et al. 2008; Zhai and Santosh 2011) (figure 1a). The NCC is divided into Eastern and Western blocks, separated by the Trans-North China Orogen (Zhao et al. 2001), and consists of Archean to Palaeoproterozoic basement overlain by Mesoproterozoic to Cenozoic cover (Zhai and Santosh 2011; Zhao and Cawood 2012; Zhao and Zhai 2012). Mesozoic geodynamics of the eastern NCC was considered to be controlled by subduction of the Palaeo-Pacific plate underneath the Asian continent and subsequent closure of the Palaeo-Asian ocean (Davis et al. 2002; Griffin et al. 1998; Wu et al. 2005a, b; Zhu et al. 2012). The NCC has experienced lithosphere thinning, intense magmatism, structural deformation since Mesozoic, which indicates the destruction of the NCC (Zhu et al. 2012), followed by the development

Keywords. Geochemistry; depositional setting; provenance; Jurassic; North China. 

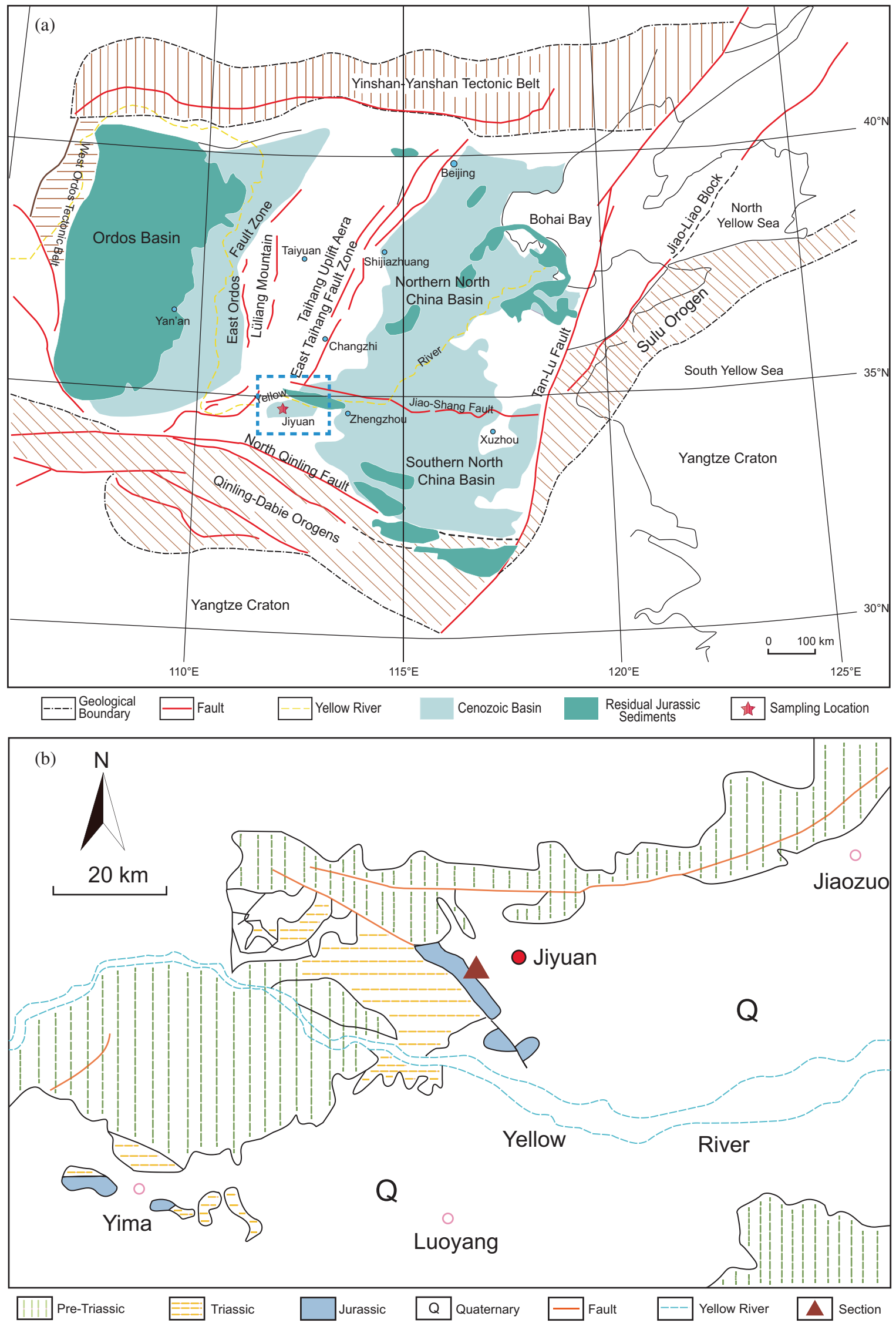

Figure 1. Simplified geological maps of Jiyuan basin, North China, showing: (a) tectonic setting of Jiyuan basin, North China (after Zhang et al. 2008) and (b) distribution of the Jurassic in western Henan Province, North China, and location of the section (modified from Zhang et al. 2005). 
of the Mesozoic basins, e.g., Ordos Basin, Bohai Bay Basin, North Yellow Sea Basin and Jiyuan Basin (Li et al. 2012). During the Middle to Late Jurassic, the tectonic regime underwent significant transformation which related to the change of sedimentary environment (Dong et al. 2000, 2007; Luo et al. 2006; Zhang et al. 2008). Jiyuan basin is located adjacent to the north-west margin of the southern NCC, and regarded as a Triassic--Jurassic synorogenic basin (figure 1a) (Liu et al. 2013; Yang et al. 2012, 2014a, b). In the past two decades, many investigations have been carried out on the tectonic settings (Zhang 1997; Yang et al. 2012, 2014a, b) and sedimentary facies (Hu et al. 2004a, b; Zhang et al. 2005) of the Jurassic in the Jiyuan basin. Previous work has largely focused on the sedimentary environment of Early-Middle Jurassic (Anyao Yangshuzhuang Formations), whereas little work has been concentrated on the sedimentary environment of late stage of Middle Jurassic (Ma'ao Formation). The provenance of Jurassic rocks in Jiyuan basin is still poorly known, and further work needs to be conducted on the basinrange coupling relationship. The discussion of Jiyuan basin during Jurassic provides insights into the evolution of the NCC.

In this paper, we present trace element (including $\mathrm{REE}$ ) data of argillaceous rocks to discuss the depositional settings, sedimentary provenances and tectonic settings of Jiyuan basin and the NCC tectonic evolution during Jurassic.

\section{Location and geological setting}

\subsection{Geological background}

The east-west-trending Jiyuan basin is bounded by the Taihang Mountains to the north, the North Qinling Orogen to the south (Zhang 1997; Yang et al. 2012). It was developed during the Late Palaeozoic-Middle Triassic, based on the large inland basin of North China (Wu 1985; Wu et al. 2000; Yang et al. 2012). It is marked by marine carbonate rocks from the Cambrian to Middle Ordovician, lack of strata from the upper Ordovician to Lower Carboniferous, coal-bearing strata of marine-terrigenous facies from the Middle Carboniferous to Permian, and red clastic deposits of fluvial facies from the Early to Middle Triassic. The Jiyuan basin remained in a steadily shrinking condition from the Late Triassic to Middle Jurassic, bearing the upper Triassic (including the Chunshuyao and Tanzhuang Formations) and Lower-Middle Jurassic (including the Anyao, Yangshuzhuang, and Ma'ao Formations) from the bottom up (Wu et al. 2000; Yang et al. 2012).

\subsection{Stratigraphy and depositional settings}

The study area comprised well-exposed Jurassic formations located in the Chengliu Town of Jiyuan
City in northwestern Henan Province, North China (figure 1b). The Upper Triassic-Middle Jurassic System are well exposed and widely distributed in Chengliu. The Jurassic rocks are subdivided into three sedimentary formations from bottom to top, i.e., Anyao, Yangshuzhuang, and Ma'ao, respectively (Hu 1991; Wu et al. 2000; Yang et al. 2014a) (figure 2).

The Anyao Formation contains mainly celadon mudstones interbedded with calcareous siltstones (figure 3a, b). Multiple types of Bouma succession (Wu 1985; Buatois et al. 1996), scouring structures and trace fossils, including Fodinichnia and Pascichnia (Wu 1985; Buatois et al. 1996; Hu et al. 2002) occurred in the Lower-Middle part, indicating a semi-deep to deep lacustrine turbidite environment. Wave ripples occurred in the fine-grained sandstones of the upper part, suggesting shallow lacustrine facies.

The overlying Yangshuzhuang Formation is characterised by feldspathic quartz sandstones interbedded with gray-yellow mudstones, and celadon mudstones and interbedded with feldspathic and lithic sandstones from bottom to up (figure 3c), bearing tabular cross-bedding, parallel bedding, wavy bedding, and asymmetric ripple marks.

The overlying unconformity stratum is the Ma'ao Formation. Riverbed conglomerates with a distinct scoured surface (figure 3d) occurred at the bottom of the Ma'ao Formation. The lower part contains mainly celadon lithic sandstones with parallel beddings (figure 3e), foreset beddings (figure 3f) and wedge cross-beddings (figure 3g), indicating intense water energy. The upper part is marked by purple mudstone interbedded with celadon mudstone with parallel beddings, smallscale cross beddings, current beddings, and lamellibranch fossils (figure 3h) from the bottom up, showing shallow-shore lacustrine facies (figure $3 \mathrm{i}, \mathrm{j}$ ).

\section{Samples and methods}

Sixteen Jurassic argillaceous rock samples were collected from the location as shown in figure 2, including four samples from the Anyao Formation, two from the Yangshuzhuang Formation, and 10 from the upper part of the Ma'ao Formation.

All the samples were ground to 200 mesh by an agate mortar after natural drying. Trace element and REE determinations of the powder samples were analysed using Agilent 7500a ICP-MS at the State Key Laboratory of Geological Processes and Mineral Resources, China University of Geosciences, Wuhan, using the method of Qi et al. (2000). The analytical precision of the REE and trace element concentrations was better than $95 \%$. Detection limits were $\leq 2 \mathrm{ppm}$ for most trace 


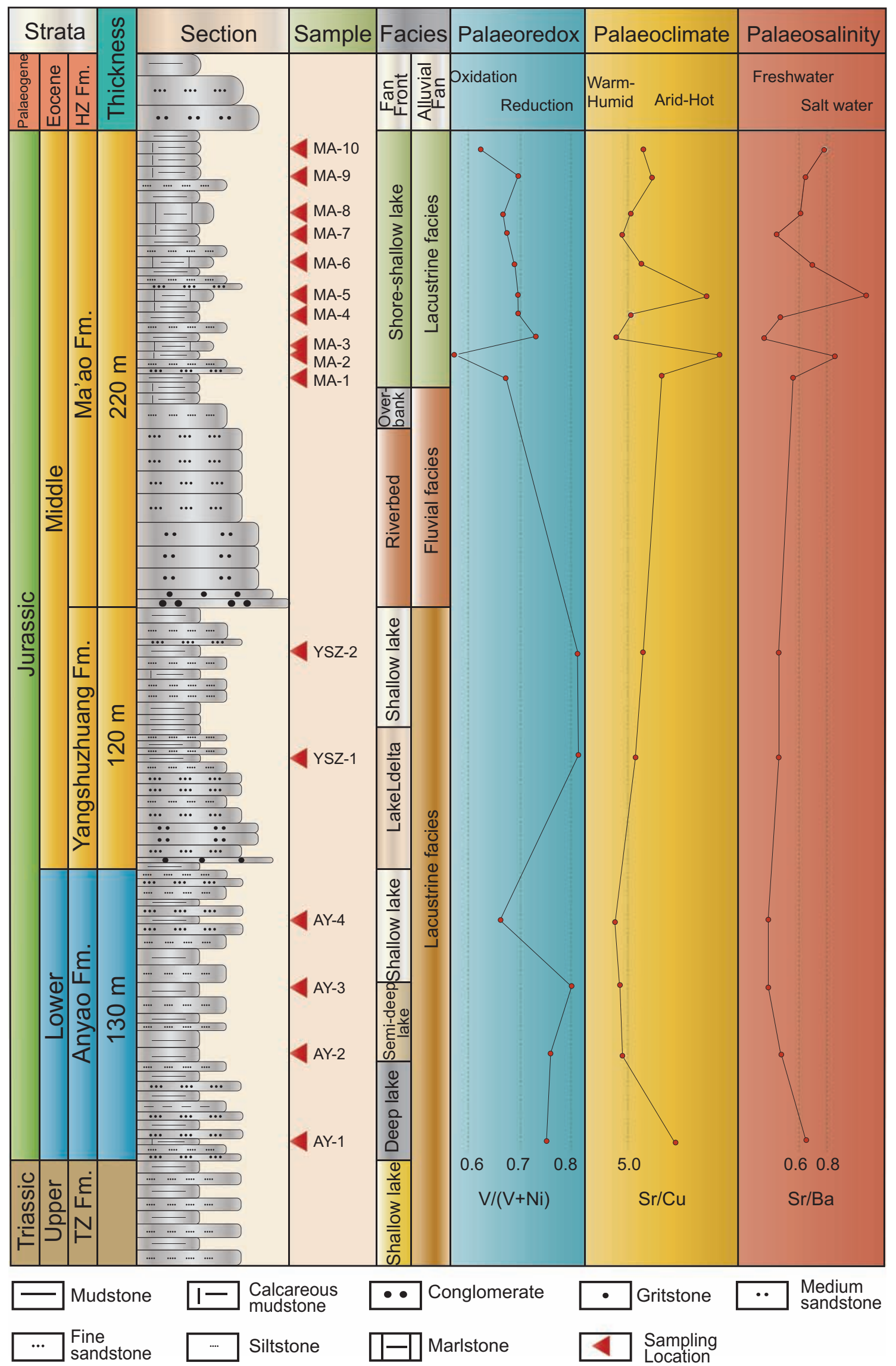

Figure 2. Stratigraphy and vertical variations of palaeo-environment of the Jurassic in Jiyuan basin. 

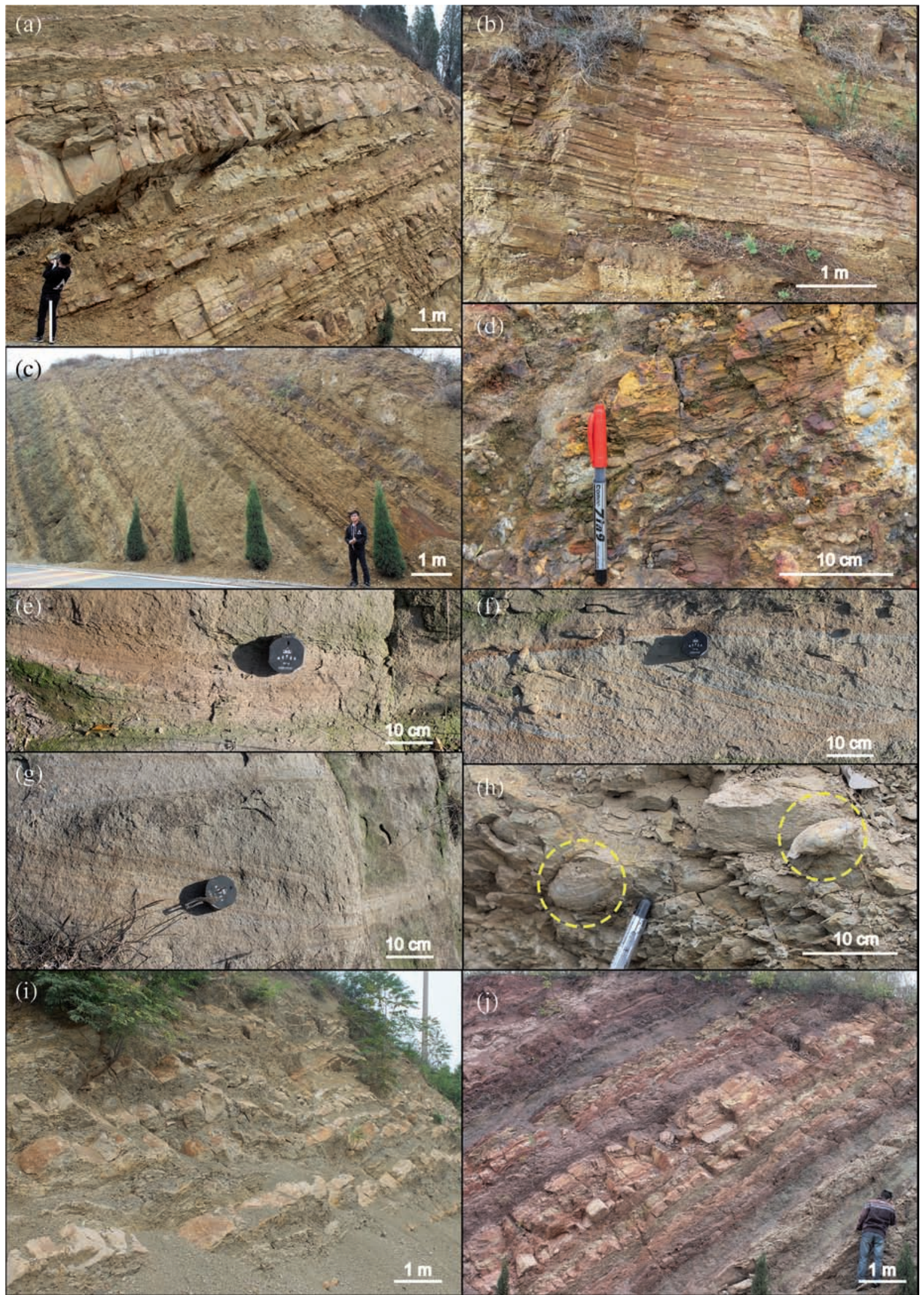

Figure 3. Jurassic outcrops in Jiyuan basin, North China. (a, b) Outcrops of Anyao Fm. showing deep to semi-deep water deposits. (c) Outcrops of the Upper Yangshuzhuang Fm. (d) Riverbed conglomerates from the lower section of Ma'ao Fm. (e) Parallel bedding. (f) Foreset bedding. (g) Wedge cross-bedding. (h) Dashed circles show lamellibranch fossils from upper section of Ma'ao Fm. (i) Outcrops of Ma'ao Fm. showing shallow lacustrine facies deposits. (g) Outcrops of Ma'ao Fm. showing shore lacustrine facies deposits. 
elements. The detection limits for $\mathrm{Ba}, \mathrm{Cr}, \mathrm{Rb}, \mathrm{Sr}$, and $\mathrm{V}$ are $5 \mathrm{ppm}$.

\section{Results}

The trace and rare earth element analysis results and other related chondrite-normalized geochemical parameters of the 16 Jurassic argillaceous rock samples from the Jiyuan basin are listed in table 1.

The total REE contents ( $\mathrm{REE}$ ) of samples from the Anyao Formation range from 151.7 to $246.0 \mathrm{ppm}$ (average $183.7 \mathrm{ppm}$ ), which is higher than the average value for the upper continental crust (UCC) (average $148.14 \mathrm{ppm}$ ) (Rudnick and Gao 2014). Samples in the Yangshuzhuang Formation appear to have higher $\Sigma$ REE values (287.6 and $251.8 \mathrm{ppm}$ ) than the average values of UCC. The $\Sigma$ REE values of samples from the Ma'ao Fm. approached the average UCC value, ranging greatly from 79.6 to 192.9 ppm (average $142.3 \mathrm{ppm}$ ). The minimum value $79.6 \mathrm{ppm}$, which corresponds to sample MA-5 (shell limestone), might have resulted from the dilution on REE concentrations by bioclasts and calcites.

All the REE data are compared with chondrite and UCC (figure 4). The chondrite-normalised REE distribution pattern (figure $4 \mathrm{a}$ ) is characterised by relative enrichment of LREE and nearly flat HREE patterns, presenting a V-shaped curve. Samples exhibit moderately negative Eu anomalies (range: $0.56-0.69 \mathrm{ppm}$, average $0.64 \mathrm{ppm}$ ) and slightly negative Ce anomalies (range: $0.83-1.01 \mathrm{ppm}$, average: $0.90 \mathrm{ppm}$ ), except for sample MA-8. The values of the LREE/HREE ratio range between 7.9 and 10.4 with an average of 9.1 , the $(\mathrm{La} / \mathrm{Yb})_{\mathrm{N}}$ ratio range from 7.92 to 13.9 with an average of 9.5, the $(\mathrm{La} / \mathrm{Sm})_{\mathrm{N}}$ ratios range between 2.85 and 5.96 with an average of 4.0, indicating strong fractionation between LREE and HREE. The $(\mathrm{Gd} / \mathrm{Yb})_{\mathrm{N}}$ ratios range from 1.07 and 2.19, with an average of 1.61, revealing slight fractionation of HREE.

Compared with UCC, the REE of the Anyao Formation is flat. The REE of the Yangshuzhuang Formation is characterised by enrichment in LREE and slightly negative Eu anomalies with the REE contents of the approximately twice average value of UCC. The REE of the Ma'ao Formation is flat with slightly positive $\mathrm{Eu}$ anomalies. As shown in figure 4, the REE patterns of Anyao Formation vary greatly and partially show affinity with the Yangshuzhuang Formation. Compared with Yangshuzhuang Formation, the Eu anomalies in Anyao Formation is much stronger. The REE pattern of Yangshuzhuang Formation shows an obvious difference from the Anyao and Ma'ao Formations.

\section{Discussion}

Trace elements (including REEs) of fine-grained clastic rocks are relatively stable in the later diagenesis and weathering processes, thus making them reliable tools for tracing the provenances and depositional settings (Bhatia and Taylor 1981; Bhatia and Crook 1986; McLennan and Taylor 1991; McLennan et al. 1993, 1995; Gu et al. 2002; Zhang 2004; Zhang et al. 2012).

\subsection{Depositional environments}

\subsubsection{Palaeoredox}

Palaeoredox conditions of ancient and modern sedimentary basins can be evaluated using various geochemical proxies (Cullers 1994, 2000; Rimmer 2004; Tribovillard et al. 2006; Huang et al. 2015). Vanadium (V) is a redox-sensitive element and is enriched in reducing sediments (Calvert and Pedersen 1993; Crusius et al. 1996; Dean et al. 1997; Algeo and Maynard 2004), making the $\mathrm{V} /(\mathrm{V}+\mathrm{Ni})$ ratio an important proxy for palaeoredox reconstruction (Hatch and Leventhal 1992; Jones and Manning 1994; Rimmer 2004; Miao et al. 2007; Yan et al. 2009; Huang et al. 2015). In average, the $\mathrm{V} /(\mathrm{V}+\mathrm{Ni})$ ratio in the Anyao Formation is 0.75 (range from 0.66 to 0.80 ), lower than that of Yangshuzhuang Formation (0.82), and higher than that of the Ma'ao Formation (range from 0.59 to 0.74 with an average of 0.67 ). The ratios suggest that all the three formations were formed in weakly stratified water columns. The lower part of the Anyao Formation records semi-deep to deep lacustrine environments (Wu 1985; Buatois et al. 1996; Hu et al. 2002), which should have strong water column stratification. However, abundant turbidite trace fossils occurred in the lower part of the Anyao Formation (Wu 1985), due to the frequent turbidite current, which may have caused weak water column stratification and provides enough oxygen for trace makers. Water depth in the Ma'ao Formation varied frequently, relating to the variation of redox condition (figure 2). The $\mathrm{Ce}_{\text {anom }}\left(\mathrm{Ce}=\mathrm{Ce}_{\mathrm{N}} /\left(\mathrm{La}_{\mathrm{N}} \times \operatorname{Pr}_{\mathrm{N}}\right)^{0.5}\right)$ has also proved to be a robust palaeoredox indicator (Elderfield and Greaves 1982). The $\mathrm{Ce}_{\text {anom }}$ index of Anyao Formation ranges from -0.03 to -0.09 , reflecting a weak oxidation-reduction condition with the reducibility gradually weakening (Elderfield and Greaves 1982). The $\mathrm{Ce}_{\text {anom }}$ indices of both the samples of Yangshuzhuang Formation are -0.08 and the $\mathrm{Ce}_{\text {anom }}$ index of the Ma'ao Formation, varies greatly from 0.01 to -0.1 , indicating a weak oxidation-reduction environment (Elderfield and Greaves 1982). The Ce/La ratios suggest that all the three formations were formed in weakly 


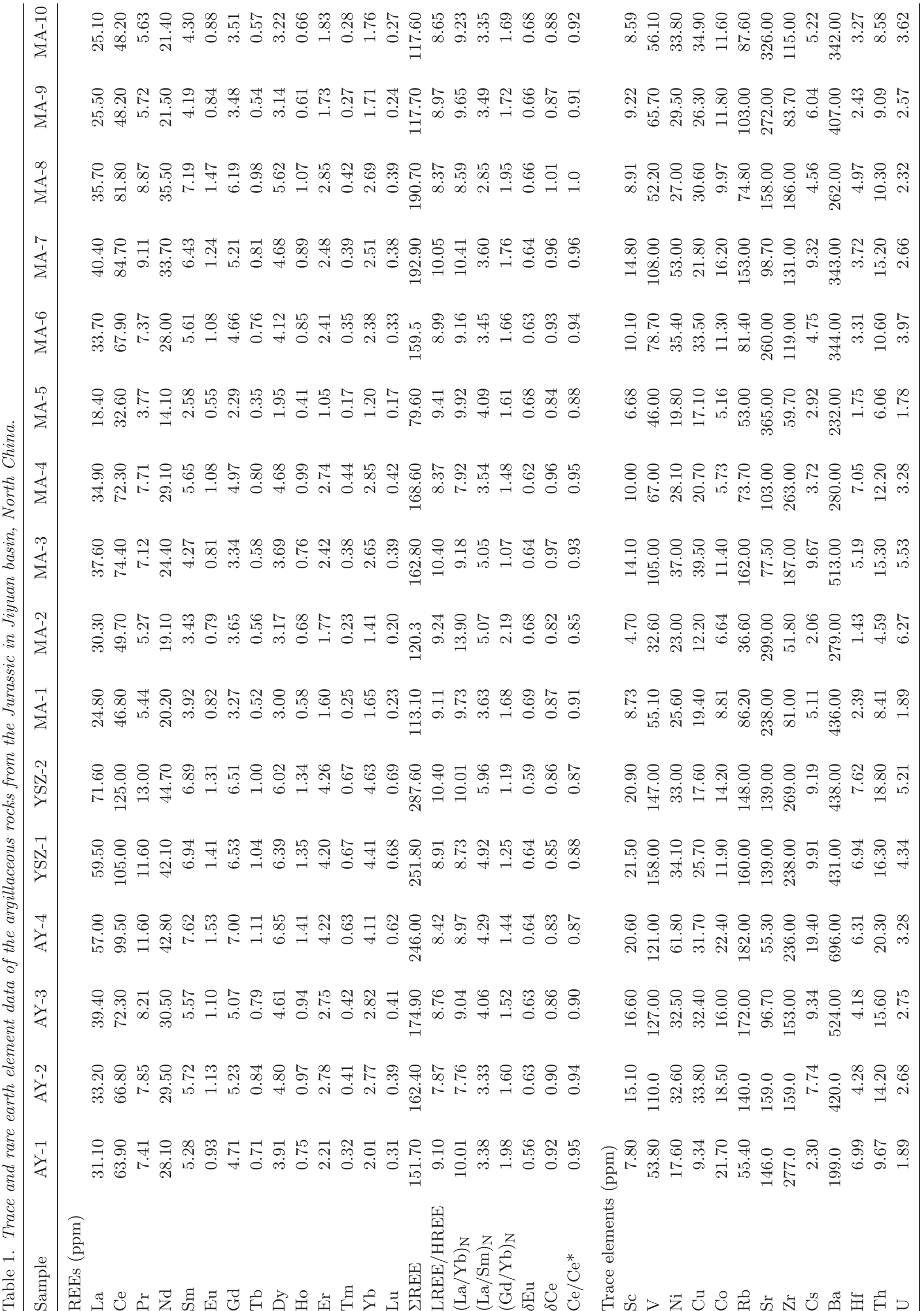


oxidising-reducing conditions (sub-oxic conditions) (Bao et al. 2011). As shown in figure 2, regional oxidising strengthened quickly, since the late stage of Middle Jurassic (Ma'ao Formation).

\subsubsection{Palaeosalinity}

The $\mathrm{Sr} / \mathrm{Ba}$ ratios were used to indicate the palaeosalinity conditions (e.g., Zheng and Liu 1999; Custodio 2002; Liu and Zhou 2007). The Sr/Ba ratios in the Anyao Formation decrease gradually from 0.73 to 0.08 , the $\mathrm{Sr} / \mathrm{Ba}$ ratios of both the samples of Yangshuzhuang Formation are 0.32, the $\mathrm{Sr} / \mathrm{Ba}$ ratios in the Ma'ao Formation vary greatly from 0.15 to 1.57 , indicating a decreasing salinity and an increasing freshwater environment in Anyao Formation, a freshwater environment in Yangshuzhuang Formation and an overall brackish environment (Zheng and Liu 1999; Custodio 2002; Liu and Zhou 2007). With water depth gradually shallowing, the salinity decreased as well, indicating a humid climate and open lacustrine environment with a large inflow of freshwater during the deposition of Anyao Formation. Palaeosalinity varied in the Ma'ao Formation, showing a similar trend to palaeoredox conditions. The negative correlation between $\mathrm{Ce} / \mathrm{La}$ and $\mathrm{Sr} / \mathrm{Ba}(\mathrm{r}=0.61)$ suggests a relatively closed basin and the inverse relationship between water depth and salinity during the deposition of the Ma'ao Formation.

\subsubsection{Palaeoclimate}

Geochemical signature of sedimentary rocks provides important information on climate (Bhatia 1983; Bhatia and Crook 1986; Adegoke et al. 2014). The $\mathrm{Sr} / \mathrm{Cu}$ ratio in lacustrine basins is used as a palaeoclimate proxy (Lerman 1978; Deng and Qian 1993; Liu and Zhou 2007; Cheng et al. 2010). The $\mathrm{Sr} / \mathrm{Cu}$ ratios in the Anyao Formation range from 1.7 to 4.7 with an average of 3.1. The $\mathrm{Sr} / \mathrm{Cu}$ ratios in Yangshuzhuang Formation are 5.4 and 7.9. The $\mathrm{Sr} / \mathrm{Cu}$ ratios in the Ma'ao Formation range greatly from 2.0 to 24.5 with an average of 10.2. The $\mathrm{Sr} / \mathrm{Cu}$ ratios suggest that the Anyao Formation mainly records a warm and humid climate, whereas the Yangshuzhuang and Ma'ao Formation indicate a quite arid climate (Cheng et al. 2010), as shown in figure 2. Samples MA-3, MA-4, and MA-7 show the frequent variations of climate in the late stage of Middle Jurassic. Additionally, Ce/La and $\mathrm{Sr} / \mathrm{Ba}$ ratios in the Ma'ao Formation indicates the positive correlation between climate and salinity. As shown in figure 2, the Jiyuan basin was deposited in a warm-humid climate in Early Jurassic, whereas it became quite arid in the late stage of Middle Jurassic, corresponding with the variation of palaeoredox and palaeosalinity conditions. 


\subsection{Provenance analysis}

REE patterns have been used as the most reliable proxies of sediment provenance (Taylor and McLennan 1985; McLennan 1989; McLennan et al. anomalies and the flat HREE patterns of the Jurassic argillaceous rock samples reveal derivation from the sources similar to UCC composed mainly of felsic components. The $(\mathrm{Gd} / \mathrm{Yb})_{\mathrm{N}}$ ratio decreases steadily with decreasing of Gd content due to the geological evolution and elemental fractionation. Based on Cheng et al. (2010), the $(\mathrm{Gd} / \mathrm{Yb})_{\mathrm{N}}$ ratio reveals that provenance of most samples areas. As shown in figure 4(b), the provenances are mainly derived from the felsic sources, whereas the provenance for Ma'ao Formation shows an obvious difference when compared with Anyao and Yangshuzhuang Formations.

The immobile trace elements (e.g., Zr, Y, Th, Sc, $\mathrm{Hf}, \mathrm{La}$ ) in the sedimentary rocks have proved to be useful in determining source rocks (Gu et al. 2002; Taylor and McLennan 1985; Wani and Mondal 2011; Mondal et al. 2012). As shown in figure 5, the samples mostly lie in the field of felsic volcanic rocks. The $\mathrm{La} / \mathrm{Yb}$ vs. REE plot (figure $5 \mathrm{c}$ ) suggests that the source rocks were granites and some older sedimentary rocks. In spite of limited data, it is clearly shown that provenance varies in different formations. The provenance for Ma'ao Formation is obviously different from Anyao and Yangshuzhuang Formations. As shown in the plots of La/Th vs. Hf (figure 5a), samples from the Ma'ao Formation probably indicate a mixed provenance comprising

\subsubsection{Nature of source rocks} 1995). The enrichment of LREEs, the negative Eu were probably derived from Post-Archean source

granites and felsic to intermediate volcanic components. Similarly, the La/Yb vs. REE plot (figure 5c) shows the different of provenance for Ma'ao Formation. Three of 10 samples in the Ma'ao Formation (MA-2, MA-9, MA-10) show high $\mathrm{Co} / \mathrm{Th}$ ratios, reflecting the influence by intermediate volcanic components. Geochemistry reveals a mixed provenance comprising recycled sedimentary rocks and felsic rocks for Anyao Formation. The provenance for Yangshuzhuang Formation exhibits difference from the Anyao and Ma'ao Formations, as shown in figure $5(\mathrm{a}, \mathrm{c})$.

\subsubsection{Tectonic setting of Jurassic sedimentary rocks of Jiyuan basin}

The Th-Co-Zr/10 and Th-Sc-Zr/10 (figure 6) plots have been used to discriminate tectonic environments (e.g., Bhatia and Crook 1986; Xu et al. 2010; Wang et al. 2012; Zhang and Liu 2015). As shown in figure 6 , most samples plot in ACA field or within ACA and CIA fields, indicating the provenance of Jurassic sediments in Jiyuan basin mainly related to ACM and CIA. Tectonic setting of samples in Ma'ao Formation is quite different from Anyao and Yangshuzhuang Formations. Samples of the Yangshuzhuang Formation plot into different fields compared with Anyao Formation.

The Th/U ratios in the Anyao Formation range from 5.12 to 6.19 , the $\mathrm{Th} / \mathrm{U}$ ratios in the Yangshuzhuang Formation are 3.76 and 3.61 and the $\mathrm{Th} / \mathrm{U}$ ratios in the Ma'ao Formation range greatly from 0.71 to 5.73 (average 3.38), whereas some of them range from 2.5 to 3.5 . The $\mathrm{Th} / \mathrm{U}$ ratios reveal that the Jurassic provenance in Jiyuan basin is marked by dominated sedimentary rock with

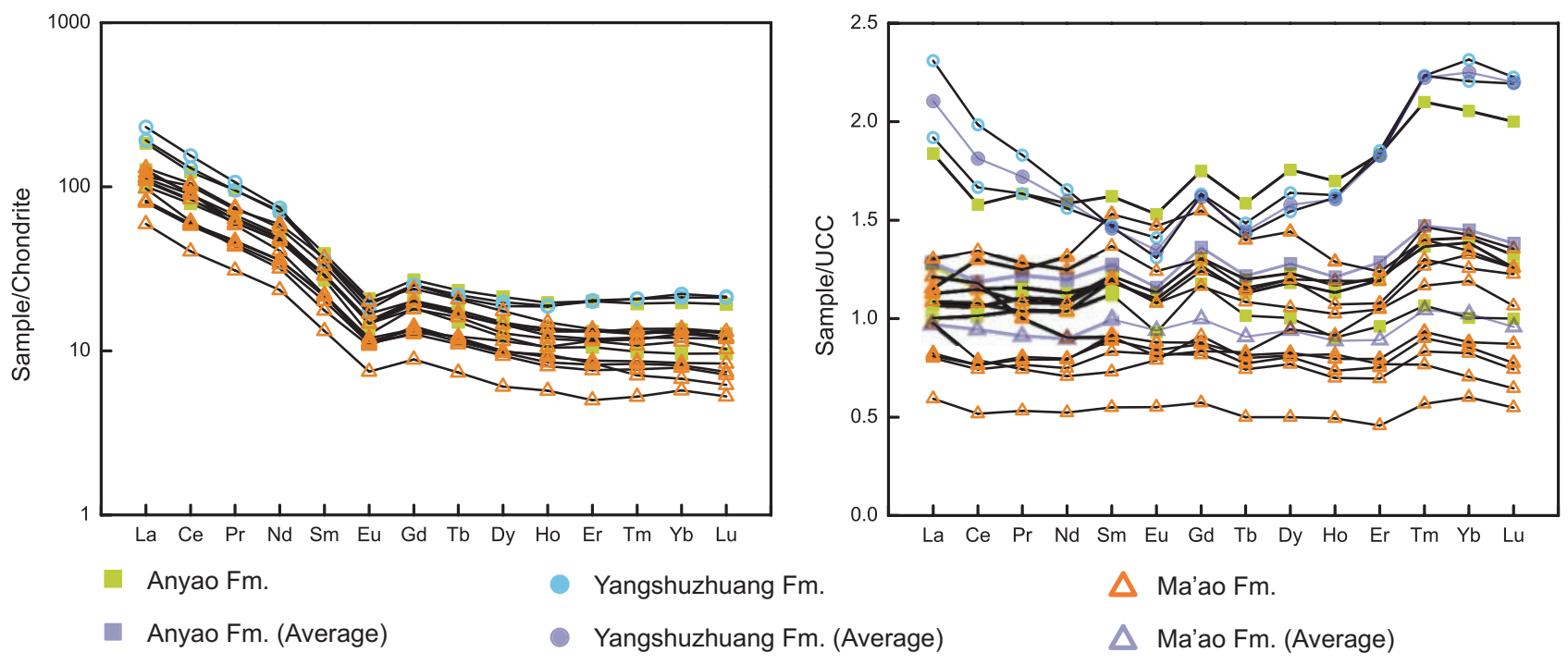

Figure 4. (a) Chondrite-normalized and (b) upper continental crust (UCC)-normalized spidergrams for Jurassic argillaceous rocks from the Jiyuan basin, North China. Chondrite values are from Boynton (1984); UCC values are from Rudnick and Gao (2014). 

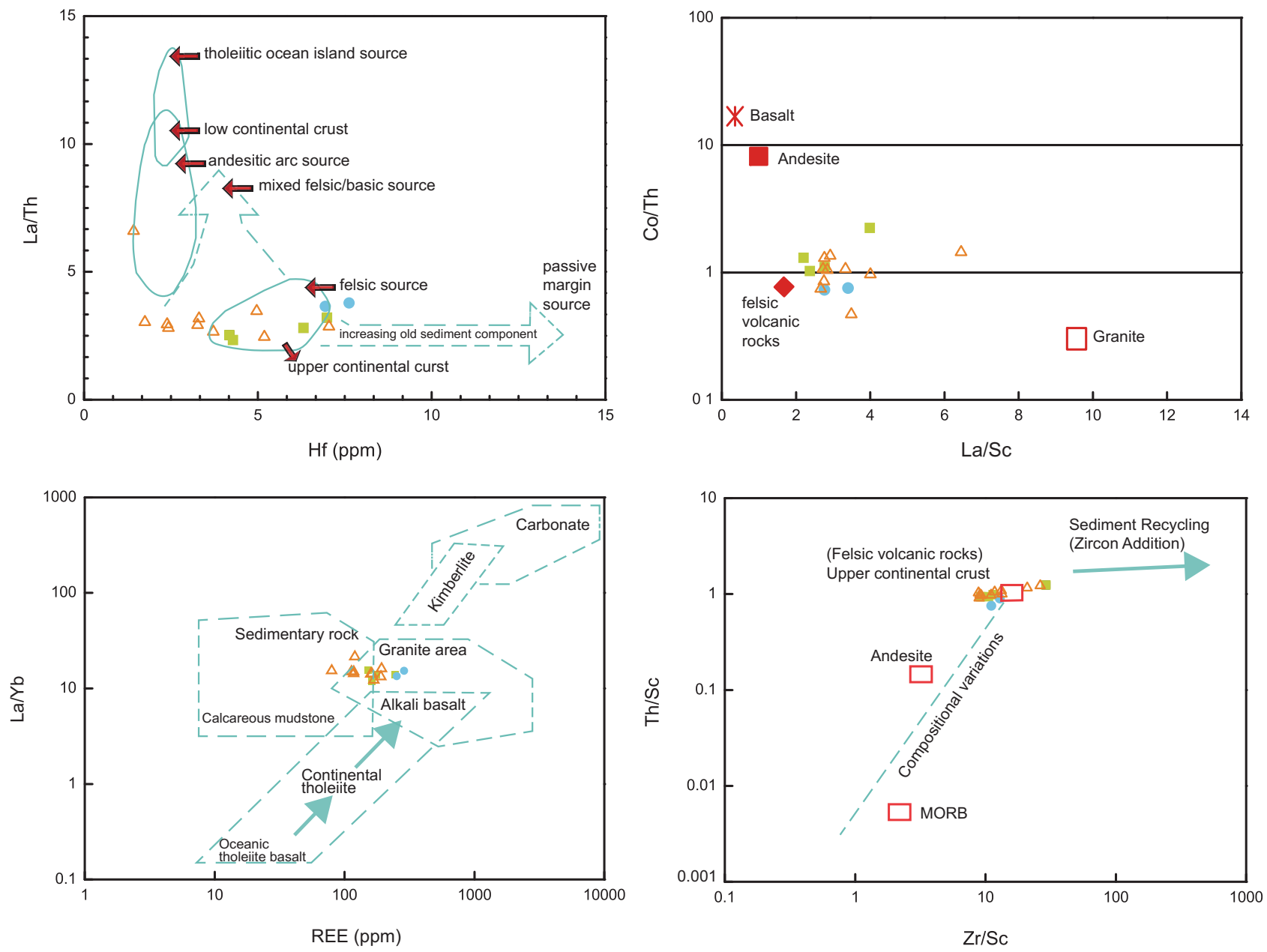

Figure 5. Plots of (a) Hf vs. La/Th (after Floyd and Leveridge 1987); (b) La/Sc vs. Co/Th (average compositions of references are from Condie (1993); (c) Total REE vs. La/Yb (after Allègre and Minster 1978); and (d) Zr/Sc vs. Th/Sc (after McLennan et al. 1993) for Jurassic argillaceous rocks from Jiyuan basin, North China.

few island-arc volcanic rocks in the Early Jurassic (Anyao Formation), massive island-arc volcanic rocks with few mixed sedimentary rocks in the early stage of Middle Jurassic (Yangshuzhuang Formation) and dominated island-arc volcanic rocks with mixed recycled sedimentary rocks in the late stage of Middle Jurassic (Ma'ao Formation) (Bhatia and Taylor 1981).

In addition, the $\mathrm{Th} / \mathrm{U}$ ratio gradually increases with increasing weathering, due to the oxidation and loss of U (Taylor and McLennan 1985; McLennan and Taylor 1991; McLennan et al. 1995). Th/U ratios $>4$ are thought to be related to weathering history (McLennan et al. 1995). As shown in the Th/U-Th plot (figure 7), the weathering of the Jurassic sedimentary rocks in Jiyuan basin gradually decreases from the bottom up (McLennan et al. 1993). The provenance for Ma'ao is quite different from Anyao and Yangshuzhuang Formations, showing variation from the source similar to UCC to the depleted mantle source (McLennan et al. 1993). Furthermore, combined with the La/Th vs. Hf plot (figure 5a), the Jurassic provenance for Jiyuan basin changed gradually from sedimentaryrock-dominated to igneous-rock-dominated from the bottom up, probably due to the convention of tectonic regimes.

\subsection{Constraints on tectonism and basin evolution}

The tectonic evolution of Jiyuan basin during Jurassic were discussed on the basis of depositional settings analysis, provenance analysis and regional geology. During Early-Middle Jurassic (ca. 201$170 \mathrm{Ma}$ ), the subduction of Palaeo-Pacific plate relate to the destruction of $\mathrm{NCC}$, followed by the development of the Jiyuan basins ( $\mathrm{Li}$ et al. 2012; Zhu et al. 2012). Taihang Mountains began to uplift in the Middle Jurassic (ca. 175-150 Ma) (Wang and Li 2008). The initial uplift stage of Taihang Mountains corresponds to the deposition of Anyao and Yangshuzhuang Formations when the 


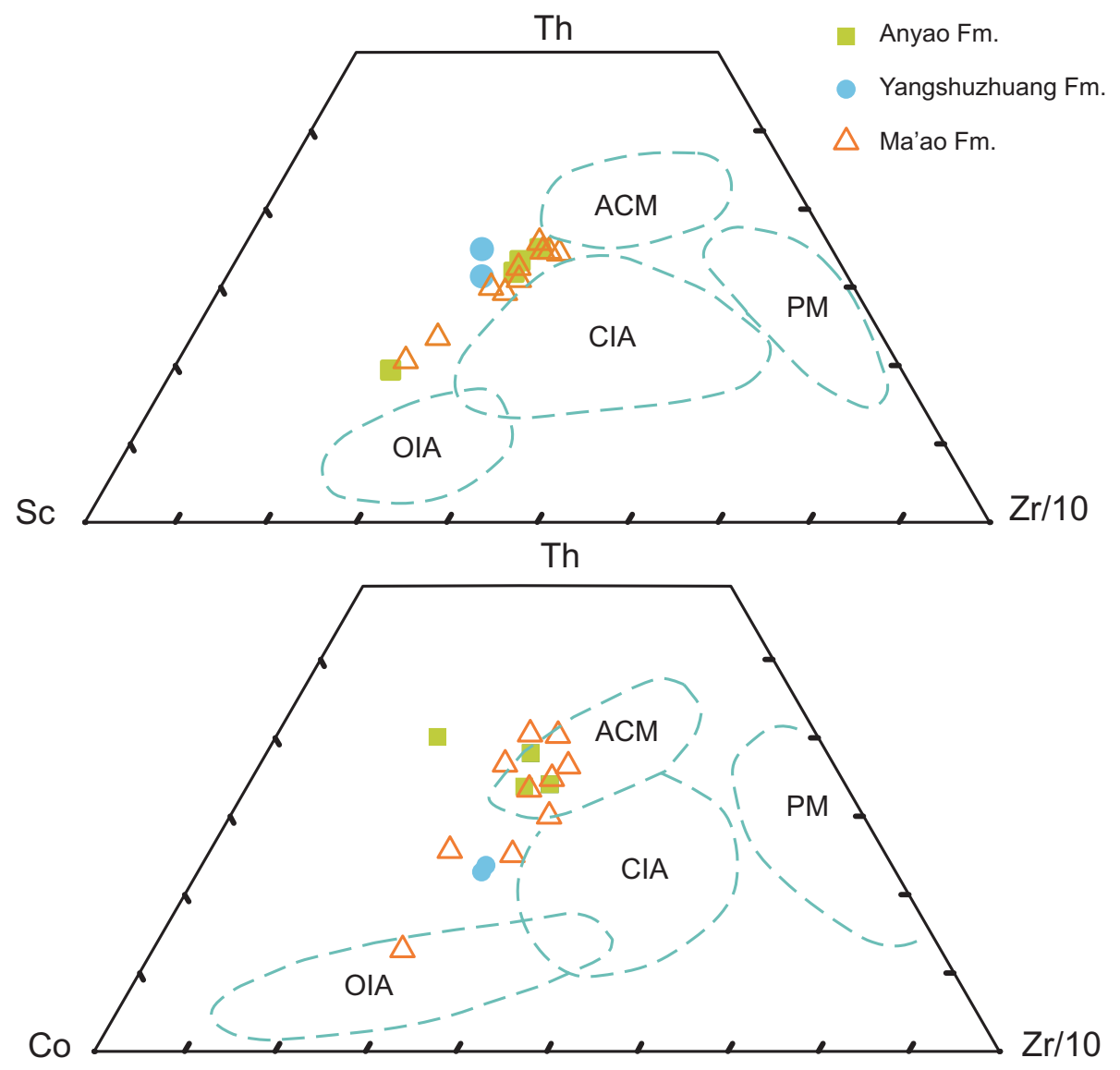

Figure 6. Ternary plots of (a) Co-Th-Zr/10 and (b) Sc-Th-Zr/10 for tectonic discrimination (after Bhatia and Crook 1986). OIA = Oceanic Island Arc, ACM = Active Continental Margin, CIA = Continental Island Arc, PM = Passive Margin.

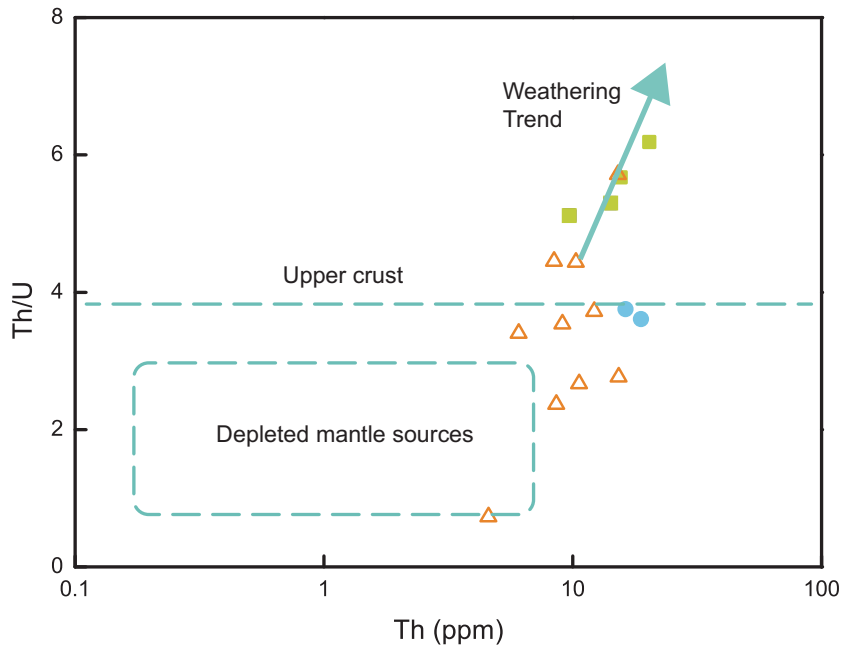

Figure 7. Plot of Th vs. Th/U for Jurassic argillaceous rocks from Jiyuan basin, North China (after McLennan et al. 1993).

Jiyuan basin belonged to the opening system of the large Ordos basin.

During the deposition of Anyao Formation, the southern fault of Jiyuan basin occurred strikeslip and extensional activities (Wu et al. 2000; Yang et al. 2012). The subsidence of Jiyuan basin resulted in the deep-water turbidite deposits in Anyao Formation, corresponding with weak extension tectonic regime of NCC. The provenances for Anyao Formation were mainly derived from the sedimentary cover and felsic rock basement of North Qinling, and partially from the recycled felsic sedimentary covers of northern Taihang Mountains.

In the early stage of Middle Jurassic (ca. $174 \mathrm{Ma}$ ), the accommodation space of Jiyuan basin was filled rapidly with the water depth shallowed. The provenance for Yangshuzhuang Formation were mainly derived from the felsic volcanic rocks of North Qinling. Detrital zircon data from Anyao and Yangshuzhuang Formations also reveal that the basement of North Qinling had been the primary provenance for Jiyuan basin (Yang et al. 2014b). The unstable conglomerates disappeared southwardly, revealing that provenance for Jiyuan basin may also derive from the Taihang Mountains during the deposition of Yangshuzhuang Formation (Yang et al. 2014b).

With the subduction of Palaeo-Pacific plate (i.e., Izanagi) which contributes to the Mesozoic tectonic transmission of the North China in Middle Jurassic (ca. $170 \mathrm{Ma}$ ) (Isozaki and Nishimura 1989; Isozaki 1997; Maruyama et al. 1997; Hou et al. 2009), 
Taihang Mountain entered into main orogenic episode. With the enhancing uplifting and eroding of Taihang Mountain, the Palaeoproterozoic-Archean basic components in the basement of NCC (Taihang Mountain) had been eroded and transported into surrounding basins (Zhai and Liu 2003; Zhai and Santosh 2011; Zhao and Zhai 2012). Jiyuan basin was isolated from the large Orods basin in the deposition of Ma'ao Formation. Jiyuan basin showed a lacustrine regressive deposition which underwent a conversion from lacustrine to fluvial facies at the bottom of the Ma'ao Formation, indicating the conversion of tectonic stress field of NCC and a rapid uplift of Jiyuan basin in the late stage of Middle Jurassic (ca. $168 \mathrm{Ma}$ ). The lithology of sandstone in Middle Jurassic varied from feldspar-quartz sandstone to lithic sandstone, and the colour of argillaceous rocks, which varied from celadon to purple, revealed the regional rapid uplift and deduction of Jiyuan basin ( $\mathrm{Li}$ et al. 2014). The regional oxidising enhanced quickly and the palaeoclimate changed from humid to arid in Middle Jurassic, corresponding with the convention of tectonic regime of NCC. The felsic provenance for Ma'ao Formation were probably still derived from North Qinling, whereas the intermediatebasic volcanic rocks comprising depleted mantle components may derive from the basement of NCC (Taihang Mountain). Detrital zircons from the Ma'ao Formation also revealed that Taihang Mountain had been the primary source to the Jiyuan basin in the late stage of Middle Jurassic (Yang et al. 2012, 2014b).

\section{Conclusion}

Based on the geochemical data of the studied Jurassic argillaceous rocks collected from the Jiyuan basin, the main conclusions are as follows:

1. The trace element proxies $\mathrm{V} /(\mathrm{V}+\mathrm{Ni}), \mathrm{Ce}_{\text {anom }}$ index, $\mathrm{Ce} / \mathrm{La}, \mathrm{Sr} / \mathrm{Ba}$, and $\mathrm{Sr} / \mathrm{Cu}$ reveal that Jiyuan basin was deposited in a weakly oxidizing-reducing condition (sub-oxic condition) with reducibility decreasing and water depth gradually shallowing from the bottom up during Jurassic. Both the Anyao and Yangshuzhuang Formations record a freshwater environment, whereas the Ma'ao Formation records a brackish water environment with frequent variations in salinity. The palaeoclimate changed from warm and humid to arid and hot in Middle Jurassic.

2. Provenance for the Jurassic argillaceous rocks in Jiyuan basin are mainly derived from felsic volcanic rocks and relate to active continental margin and continental island arc, with felsic source gradually reducing and basic components increasing from the bottom up.
3. In the Early-Middle Jurassic (Anyao and Formations), North Qinling has provided the main provenance for the Jurassic sedimentary rocks in Jiyuan basin. The subduction of PalaeoPacific plate in Middle Jurassic related to the uplift of Taihang Mountain. Taihang Mountain has been the primary source to the Jiyuan basin in the late stage of Middle Jurassic.

\section{Acknowledgements}

We express our sincere thanks to the reviewer and editor of the Journal of Earth System Science who offered helpful and insightful comments. We would like to thank Dr Wentao Yang and Pengfei Zuo for their thoughtful advices on improving this manuscript. Thanks are also given to $\mathrm{Lu}$ Zhou, Yong Cheng, Pengxiao Wang and Fengbo Sun for their help in the fieldwork. This work was supported by the Chinese NSFC grant \#41272118.

\section{References}

Adegoke A K, Wan H A, Hakimi M H, Yandoka B M S, Mustapha K A and Aturamu A O 2014 Trace elements geochemistry of kerogen in upper cretaceous sediments, Chad (Bornu) Basin, northeastern Nigeria: Origin and paleoredox conditions; J. African Earth Sci. 100 675-683.

Algeo T J and Maynard J B 2004 Trace-element behaviour and redox facies in core shales of Upper Pennsylvanian Kansas-type cyclothems; Chem. Geol. 206(3) 289-318.

Allègre C J and Minster J F 1978 Quantitative models of trace element behaviour in magmatic processes; Earth Planet. Sci. Lett. 38 1-25.

Bao H Y, Yang F L, Wang D P, Yu H X and Wu Z 2011 Geochemical characteristics of sedimentary rock in Southern Jiangsu Province on Mesozoic and Palaeozoic: A perspective from the Shengke-1 Well; J. Jilin Univ. (Earth Sci. Ed.) 41(1) 29-37 (in Chinese with English Abstract).

Bhatia M R 1983 Plate tectonics and geochemical composition of sandstones; J. Geol. 91 611-627.

Bhatia M R and Crook K A W 1986 Trace element characteristics of graywackes and tectonic setting discrimination of sedimentary basins; Contrib. Mineral. Petrol. 92(2) 181-193.

Bhatia M R and Taylor S R 1981 Trace element geochemistry and sedimentary provinces: A study from the Tasman Geosyncline, Australia; Chem. Geol. 33(1-2) 115-125.

Boynton W V 1984 Cosmochemistry of the rare earth elements: Meteorite studies; Research 2 63-114.

Buatois L A, Mangano M G, Wu X T and Zhang G C 1996 Trace fossils from Jurassic Lacustrine turbidites of the Anyao Formation (central China) and their environmental and evolutionary significance; Ichnos. 4(4) 287-303.

Calvert S E and Pedersen T F 1993 Geochemistry of recent oxic and anoxic sediments: Implications for the geological record; Mar. Geol. 113(1) 67-88.

Cheng Y H, Yu X H, Han B Q, Du H F and Bai Z H 2010 Geochemical characteristics of the 3rd member of Palaeogene Shahejie Formation in Dongpu Depression and their geological implications; Geology in China 37 357-366 (in Chinese with English abstract). 
Condie K C 1993 Chemical composition and evolution of the upper continental crust: Contrasting results from surface samples and shales; Chem. Geol. 104(1) 1-37.

Crusius J, Calvert S, Pedersen T and Sage D 1996 Rhenium and molybdenum enrichments in sediments as indicators of oxic, suboxic and sulfidic conditions of deposition; Earth Planet. Sci. Lett. 145(1) 65-78.

Cullers R L 1994 The chemical signature of source rocks in size fractions of Holocene stream sediment derived from metamorphic rocks in the Wet Mountains region, USA; Chem. Geol. 113 327-343.

Cullers R L 2000 The geochemistry of shales, siltstones and sandstones of Pennsylvanian-Permian age, Colorado, USA: Implications for provenance and metamorphic studies; Lithos 51(3) 181-203.

Custodio E 2002 Aquifer overexploitation: What does it mean?; Hydrogeol. J. 10(2) 254-277.

Davis G A, Darby B J, Zheng Y and Spell T L 2002 Geometric and temporal evolution of an extensional detachment fault, Hohhot metamorphic core complex, Inner Mongolia, China; Geology 30(11) 1003-1006.

Dean W E, Gardner J V and Piper D Z 1997 Inorganic geochemical indicators of glacial-interglacial changes in productivity and anoxia on the California continental margin; Geochim. Cosmochim. Acta 61(61) 4507-4518.

Deng H W and Qian K 1993 Sedimentary Geochemistry and Environment Analysis, Lanzhou; Gansu Science and Technology Press, pp. 95-104 (in Chinese).

Dong S W, Wu X H, Wu Z H, Deng J F, Gao R and Wang C S 2000 On tectonic seesawing of the East Asia continent-Global implication of the Yanshanian movement; Geol. Rev. 46(1) 8-13 (in Chinese with English abstract).

Dong X W, Zhang Y Q, Long C X, Yang Z Y, Ji Q, Wang T, $\mathrm{Hu} \mathrm{J} \mathrm{M}$ and Chen X H 2007 Jurassic tectonic revolution in China and new interpretation of the Yanshan Movement; Acta Geol. Sin. 81(11) 1449-1461.

Elderfield H and Greaves M J 1982 The rare earth elements in seawater; Nature 296(5854) 214-219.

Floyd P A and Leveridge B E 1987 Tectonic environment of the Devonian Gramscatho basin, South Cornwall: Framework mode and geochemical evidence from turbiditic sandstones; J. Geol. Soc. 144(4) 531-542.

Griffin W L, Zhang A, O'Reilly S Y and Ryan C G 1998 Phanerozoic evolution of the lithosphere beneath the Sino-Korean Craton, In: Mantle dynamics and plate interaction in East Asia (eds) Flower M F J, Chung S L, Lo C H and Lee T Y; Geodyn. Ser. 27 107-126.

Gu X X, Liu J M, Zheng M H and Qi L 2002 Provenance and tectonic setting of the Proterozoic turbidites in Hunan, South China geochemical evidence; J. Sedim. Res. 72(3) 393-407.

Haskin L A, Haskin M A, Fery F A and Wildeman T R 1968 Relative and absolute terrestrial abundances of the rare earths; Origin and Distribution of the Elements, pp. 1889-911.

Hatch J R and Leventhal J S 1992 Relationship between inferred redox potential of the depositional environment and geochemistry of the Upper Pennsylvanian (Missourian) Stark Shale Member of the Dennis Limestone, Wabaunsee County, Kansas, USA; Chem. Geol. 99(1) 65-82.

Hou G T, Yang M H and Yao W H 2009 The destruction of the North China craton: Evidences from the extensions; J. Virtual Explorer 29 10-17.

Hu B 1991 The Late Triassic and Middle Jurassic continental strata in Jiyuan, Henan; J. Stratigraphy 15(1) 48-52 (in Chinese with English Abstract).

Hu B, Qi Y A, Zhang G C and Jiang Z X 2002 The Ichnocoenoses of Mesozoic-Cenozoic terrestrial deposits of China; Acta Sedim. Sin. 20(4) 574-581 (in Chinese with English Abstract).
Hu B, Zhang G C, Guo W X, Qi Y A and Zhang L W 2004a The Stipsellus ichnofabric in the fluvial deposits of Upper Triassic Tanzhuang Formation in Jiyuan, western Henan; Coal Geol. Explor. 32(3) 1-4 (in Chinese with English Abstract).

Hu B, Zhang L W, Qi Y A and Guo W X 2004b Sedimentary structures and environments of Lower Jurassic Anyao Formation, Jiyan, Central China; J. Jiaozuo Instit. Technol. (Natural Science) 23(1) 18-22 (in Chinese with English Abstract).

Huang J H, Huang F, Evans L and Glasauer S 2015 Vanadium: Global (bio)geochemistry; Chem. Geol. 417 68-89.

Isozaki Y 1997 Jurassic accretion tectonics of Japan; The Island Arc 6(1) 25-51.

Isozaki Y and Nishimura Y 1989 Fusaki Formation, Jurassic subduction-accretion complex on Ishigaki island, southern Ryukyus and its geologic implication to late Mesozoic convergent margin of east Asia; Geol. Soc. Japan Memoir 33 259-275.

Jones B and Manning D A C 1994 Comparison of geochemical indices used for the interpretation of palaeoredox conditions in ancient mudstone; Chem. Geol. 111(1) 111-129.

Lerman A 1978 Lakes: Chemistry, Geology, Physics; Springer-Verlag, Berlin Heidelberg, 368p.

Li S Z, Zhao G C, Dai L M, Liu X, Zhou L H, Santosh M and Suo Y H 2012 Mesozoic basins in eastern China and their bearing on the deconstruction of the North China Craton; J. Asian Earth Sci. 47(1) 64-79.

Li Z H, Dong S W and Qu H J 2014 Sedimentary evidences of Jurassic Orogenic Process and key time limit on the northern margin of North China Craton; J. Jilin Univ.: Earth Sci. Ed. 44(5) 1553-1574 (in Chinese with English Abstract).

Liu G and Zhou D S 2007 Application of microelements analysis in identifying sedimentary environment - Taking Qianjiang Formation in the Jianghan Basin as an example; Petrol. Geol. Exp. 29(3) 307-310 (in Chinese with English Abstract).

Liu S F, San S and Zhang G W 2013 Early Mesozoic basin development in North China: Indications of cratonic deformation; J. Asian Earth Sci. 62 221-236.

Luo Z H, Wei Y, Xin H T, Ke S, Li W T, Li D D and Huang J X 2006 The Mesozoic intraplate orogeny of the Taihang Mountains and the thinning of the continental lithosphere in North China; Earth Sci. Front. 13(6) 52-63 (in Chinese with English Abstract).

Maruyama S, Isozaki Y, Kimura G and Terabayashi M 1997 Paleogeographic maps of the Japanese islands: Plate tectonic synthesis from $750 \mathrm{Ma}$ to the present; The Island Arc 6 121-142.

McLennan S M 1989 Rare earth elements in sedimentary rocks: Influence of provenance and sedimentary processes; Rev. Mineral. Geochem. 21(1) 169-200.

McLennan S M and Taylor S R 1991 Sedimentary rocks and crustal evolution: Tectonic setting and secular trends; J. Geol. 99(1) 1-21.

McLennan S M, Hemming S R, McDaniel D K and Hanson G N 1993 Geochemical approaches to sedimentation, provenance, and tectonic; GSA Spec. Publ. 284 21-40.

McLennan S M, Hemming S R, Taylor S R and Erikkson K A 1995 Early Proterozoic crustal evolution: Geochemical and $\mathrm{Nd}-\mathrm{Pb}$ isotopic evidence from metasedimentary rocks, southwestern North America; Geochim. Cosmochim. Acta 59(6) 1153-1177.

Miao J Y, Zhao J S, Liu C Y, Zhu Y J and Wang W L 2007 Relationship between the geochemical characteristics and sedimentary environment of Permian hydrocarbon source rocks in the Orods basin; Geol. China 34(3) 430-435 (in Chinese with English abstract). 
Mondal M E A, Wani H and Mondal B 2012 Geochemical signature of provenance, tectonics and chemical weathering in the quaternary flood plain sediments of the Hindon river, Gangetic plain, India; Tectonophys. 566-567(3) 87-94.

Qi L, Jing H and Gregoire D C 2000 Determination of trace elements in granites by inductively coupled plasma mass spectrometry; Talanta 51(3) 507-513.

Rudnick R L and Gao S 2014 Composition of the continental crust; Treatise on geochemistry (Second Edition), pp. 41-51.

Rimmer S M 2004 Geochemical palaeoredox indicators in Devonian-Mississippian black shales, central Appalachian basin (USA); Chem. Geol. 206(3-4) 373-391.

Taylor S R and McLennan S M 1985 The continental crust: Its composition and evolution; J. Geol. 94(4) 312p.

Tribovillard N, Algeo T J, Lyons T and Riboulleau A 2006 Trace metals as paleoredox and paleoproductivity proxies: An update; Chem. Geol. 232(1-2) 12-32.

Wang Y and Li H M 2008 Initial formation and Mesozoic tectonic exhumation of an intracontinental tectonic belt of the northern part of the Taihang Mountain Belt, Eastern Asia; J. Geol. 116(2) 155-172.

Wani H and Mondal M E A 2011 Evaluation of provenance, tectonic setting, and paleoredox conditions of the Mesoproterozoic-Neoproterozoic basins of the Bastar craton, Central Indian Shield: Using petrography of sandstones and geochemistry of shales; Lithosphere $\mathbf{3 ( 2 )}$ $143-154$.

Wang W, Zhou M F, Yan D P and Li J W 2012 Depositional age, provenance, and tectonic setting of the Neoproterozoic Sibao Group, southeastern Yangtze Block, South China; Precamb. Res. 192-195(1) 107-124.

Wu X T 1985 Trace fossils and their environmental significance in non-marine turbidite deposits from JiuyanYima basin, Western Henan; Acta Sedim. Sin 3(3) 23-31, 137-138 (in Chinese with English Abstract).

Wu Z P, Ma Z P and Zhou Y Q 2000 Geochemical characters of sedimentary system in the Triassic-Jurassic boundary section of Jiyuan basin; J. Univ. Petrol. China 26(3) 2025 (in Chinese with English Abstract).

Wu F Y, Lin J Q, Wilde S A, Zhang X O and Yang J H 2005a Nature and significance of the Early Cretaceous giant igneous event in Eastern China; Earth Planet. Sci. Lett. 233(1) 103-119.

Wu F Y, Yang J H, Wilde S A and Zhang X O 2005b Geochronology, petrogenesis and tectonic implications of Jurassic granites in the Liaodong peninsula, NE China; Chem. Geol. 221(1-2) 127-156.

Xu Y J, Du Y S, Yang J H and Huang H 2010 Sedimentary geochemistry and provenance of the lower and middle Devonian Laojunshan Formation, the north Qilian orogenic belt; Sci. China Earth Sci. 53(3) 356-367.

Yan D T, Chen D Z, Wang Q C and Wang J G 2009 Geochemical changes across the Ordovician-Silurian transition on the Yangtze Platform, South China; Sci. China 52(1) 38-54 (in Chinese with English Abstract).

Yang W T, Yang J H, Wang X F and Du Y S 2012 Geochronology from Middle Triassic to Middle Jurassic Detrital Zircons in Jiyuan Basin and its implications for the Qinling Orogen; Earth Sci. - J. China Univ. Geosci. 37(3) 489-500 (in Chinese with English Abstract).
Yang W T, Wang M and Du Y S 2014a The depositional characteristics from Mesozoic Jiyuan Basin with its response to the uplift of Qinling Qrogen and Taihang Mountains; Geol. Rev. 60(2) 206-274.

Yang W T, Yang J H, Wang X F and Du Y S 2014b Upliftdenudation history of the Qinling orogen: Constrained from the detrital-zircon $\mathrm{U}-\mathrm{Pb}$ geochronology; J. Asian Earth Sci. 89(3) 54-65.

Zhai M G and Liu W J 2003 Palaeoproterozoic tectonic history of the North China craton: A review; Precamb. Res. 122(1-4) 183-199.

Zhai M G and Santosh M 2011 The early Precambrian odyssey of the north China Craton: A synoptic overview; Gondwana Res. 20(1) 6-25.

Zhang K J 1997 The north and south China collision along the eastern and southern North China margins; Tectonophys. 270(12) 145-156.

Zhang K J 2002 Escape hypothesis for north and south China collision and tectonic evolution of the Qinling Orogen, eastern Asia; Eclogae Geol. Helv. 95(2) 237-247.

Zhang K J 2004 Secular geochemical variations of the Lower Cretaceous siliciclastic rocks from central Tibet (China) indicate a tectonic transition from continental collision to back-arc rifting; Earth Planet. Sci. Lett. 229(1) $73-89$.

Zhang M and Liu Z 2015 Geochemistry of pelitic rocks from the Middle Permian Lucaogou Formation, Sangonghe area, Junggar basin, Northwest China: Implications for source weathering, recycling, provenance and tectonic setting; Geol. J. 50(8) 552-552.

Zhang G C, Zeng Y F, Buatois L A and Mangano M G 2005 Lacustrine deposits and associated trace fossils in the Upper Part of the Tanzhuang Formation (T2-3), Jiyuan Basin, Henan Province; Acta Sedim. Sin. 23(1) 100-107 (in Chinese with English Abstract).

Zhang Y Q, Dong S W, Zhao Y and Zhang T 2008 Jurassic tectonics of North China: A synthetic view; Acta Geol. Sin. 82(2) 310-326.

Zhang K J, Li B and Wei Q G 2012 Geochemistry and Nd isotopes of the Songpan-Ganzi Triassic turbidites, central China: Diversified provenances and tectonic implications; J. Geol. 120(1) 69-82.

Zhao G C and Cawood P A 2012 Precambrian geology of China; Precamb. Res. 222 13-54.

Zhao G C and Zhai M G 2012 Lithotectonic elements of Precambrian basement in the North China Craton: Review and tectonic implications; Gondwana Res. 23(4) 1207-1240.

Zhao G C, Wilde S A, Cawood P A and Sun M 2001 Archaean blocks and their boundaries in the North China Craton: Lithological, geochemical, structural and $\mathrm{P}-\mathrm{T}$ path constraints and tectonic evolution; Precamb. Res. $10745-73$.

Zhao G C, Sun M, Wilde S A and Li S Z 2005 Late Archean to Paleoproterozoic evolution of North China Craton: Key issues revisited; Precamb. Res. 136 177-202.

Zheng R C and Liu M Q 1999 Study on palaeosalinity of Chang-6 oil reservoir set in Ordos Basin; Oil Gas Geol. 20(1) 20-25 (in Chinese with English Abstract).

Zhu R X, Yang J H and Wu F Y 2012 Timing of destruction of the North China Craton; Lithos. 149(4) 51-60. 